\title{
(n)

\section{STRATEGIES FOR ENHANCING PEACE EDUCATION FOR NATIONAL SECURITY IN NIGERIA}

\section{Dr. Isaac N. Nwankwo}

Department of Educational Management and Policy, Nnamdi Azikiwe University, Awka.

\section{Dr. Gladys Uzoechina}

Department of Educational Foundations, Chukwuemeka Odumegwu Ojukwu University, Igbariam Campus

\section{ABSTRACT}

This work is a product of library research. The purpose was to discuss national security in Nigeria in relation to peace education. The concepts of peace education and national security were presented. The reasons for national security were discussed. The researchers also articulated the efforts so far made in Nigeria to promote national security. The work also articulated the importance of peace education to national security. The major challenges to national security in Nigeria were highlighted and strategies for enhancing peace education for national security were documented. Part of the suggestions was that elders at family and society levels should show good examples and inculcate in the children, the culture of tolerance and coexistence in the plural society, as well as teaching them patriotism and civic responsibilities to the nation over and above allegiance to tribe or ethnicity as a way of achieving national security in Nigeria.
${ }^{*}$ Correspondence to Author:

Dr. Isaac N. Nwankwo

doctorisaacnwankwo@gmail.com Department of Educational Management and Policy, Nnamdi Azikiwe University, Awka.

How to cite this article:

Isaac N. Nwankwo and Gladys Uzoechina. STRATEGIES FOR ENHANCING PEACE EDUCATION FOR NATIONAL SECURITY IN NIGERIA . American Journal of Educational Research and Reviews, 2017,2:2.

\section{eSciencePublisher 。 eSciPub LLC, Houston, TX USA. Website: http://escipub.com/}




\section{Introduction}

Nigeria is a country blessed with abundant

societies. Peace connotes tranquility, human and natural resources.

psychological consonance, physical and The country needs peace and security to environmental stability and the sustenance of survive. Peace and security are also needed enabling circumstances that guarantee freedom for national development. Peace is often from all sources of all individual and societal considered as the fundamental basis of instability. stability, progress and development in human

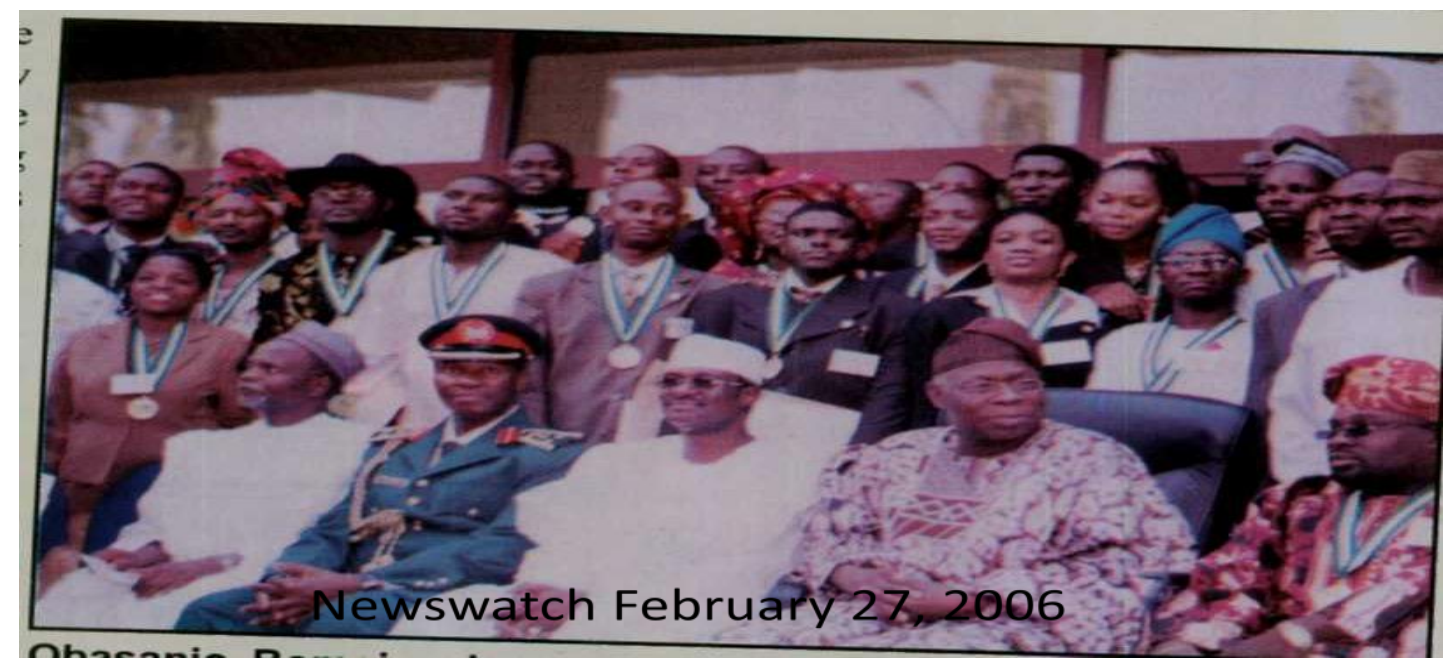

Societies and nations develop in peace, Nigeria for example, people talk of 'Nigerian cultures promote peace, religions uphold and nation' when reference is made to Nigeria as a cherish peace and individuals prosper in peace. nation. There are also 'Igbo nation ', 'Yoruba The alternatives to peace include chaos, instability, upheavals, violence and in extreme nation and 'Hausa nation' for instance. In fact, Nigeria has over 250 tribes and each of them cases, war. But, this is not to suggest that peace simply means the absence of war. lays claim to nationhood. Within the tribes too, there are sub-tribes that still refer to themselves Peace education, whether taught formally or mainstreamed informally is about the building and sustenance of positive attitudes and instilling of values and skills coupled with emphasis on elements of peace among the different individuals and segments in the society. Peace education is important for national security.

For a better understanding of the term, 'national security' there is need to clarify some issues. In as nations. So when one says national security, the referent object may be the nation when the actual meaning applies to the state. The major reason therefore depends on the composition of the nation or state. In the case of nationstates like Norway and Japan, this confusion does not matter much, but in the case of multination states like Nigeria, Russian and UK or where the nation is distributed across more than one state such as Nigeria, Korea or 
Russia, it matters because the nation and the opposed referent objects (Nigeria nation, Igbo nation, Hausa nation Yoruba nation, ljaw nation etc). In this regard, the referent objects of security are that which is (said to be) threatened, and which needs to be preserved. In this study, Nigeria is the referent object.

In any case, national security is particularly potent because the state claims to be the highest form of political organisation, and because states possess both much of the legitimacy and much of the capacity to act in the name of security. Security therefore becomes the key function of the state. In the strength of the above, it has its own claim to a right of survival and self-defence which is different from the sum of the individual rights to security of its citizens (and may up to a point be contradictory with them: e.g. conscription). In the general analysis, when the state is both referent object and principal provider of security, there is a strong territorial and statecentric framing given to the understanding of national security.

Traditionally, national security refers to the survival of the state against military threats posed by other states. This legacy continues to colour the meaning of national security, both in terms of threats being existential, and in a strong emphasis on military threats and responses. Because of this legacy, the rhetorical force of 'national security' can be used to justify exceptional measures (use of force, suspension of civil liberties, secrecy, increase of executive powers, extra-legal state may be different and activity) in a way that other types of security (principally social security) cannot. It is important to add that national security in this sense presupposes a strong state (where government and society enjoy a high degree of consensual integration). Accordingly, the concept of national security is difficult to apply to weak states where there are low integration between government and society and high levels of coercion) because feuding parts will make their own security claims against each other.

In Nigeria therefore, national security connotes the ability of Nigeria to advance her interests and objectives, to contain instability, control crime, eliminate corruption, improve the welfare, and quality of life of every citizen (Obasanjo, 1999). The above definition suggests that law and order are among the core issues of national security. In his interpretation of the aforesaid definition, Mohammed (2006) concludes that national security from any perspective is about safeguarding the interests of the citizenry and providing the type of atmosphere that is free of threats that could inhibit the pursuit of the good of all. It is about the processes and measures required to preserve law and order.

In this work, national security is defined as the aggregate of the security interest of all individuals, communities, ethnic groups, political entities and institutions which inhabit a given territory.

\section{Reasons for National Security in Nigeria}


- Nigeria is a country blessed with abundant human and material resources.

- The country has oven 250 ethnic nationalities e.g. Igbo, Hausa/Fulani, Yoruba, Kanuri, Ibibio, Tiv, Izon (ljaw), Edo, Nupe etc.

- Virtually, all the ethnic groups have distinct cultures and other things peculiar to them.

- Religiously, Northern Nigeria is principally Muslims, the East is mainly Christians while the West is an admixture of the two religion, but with Christian dominance. The African traditional religion (ATR) is also practised in the country.

\section{Nigeria's Efforts at National Security}

Nigeria as a country has formulated policies, carried out programmes and established institutions in order to promote national security through national unity. Some of them are as follows:

- Wazobia: This was an effort by the past military regime in the country to blend the languages of the three major ethnic groups into one national languageWAZOBIA. Programmes on radio and television were broadcast in the three major languages- Wa- Yoruba; ZoHausa; Bia - Igbo.

- National Youth Service Corps (NYSC): This was established by Decree No. 24, May 22, 1973 for fresh graduates under the age of 30 years.
- Unity Schools: The federal government established Federal Colleges known as Unity Schools in all states of the Federation.

- Federal Character Commission: The aim of the commission is to ensure that every state of the federation is given a fair representation at any federal establishment, programme or project.

- Sports and Cultural Festivals: Sports and cultural festivals are organised at the state and federal levels with the competing teams coming from different states. They help in the exchange of ideas and development of team spirits which are good for national security.

- Nigerian Defence Academy (NDA): Qualified people from all parts of the country go to the academy for military training. Apart from military training, the people share a lot of things in common. They go to war together to defend their fatherland

\section{Importance of Peace Education to National}

\section{Security}

1. Peace frees the individual from anxiety and insecurity thereby creating happiness.

2. It creates a good environment for people to be creative and productive. Therefore, it enhances development.

3. Peace ensures group security and solidarity.

4. When there is no peace as in wartime, educational, economics, political and social activities are disrupted. School children can no longer freely go to school; many people are 
killed; many more are thrown out of their homes. Generally, people are not happy to do their work.

5. Peace also enables human populations to grow.

6. It promotes unity and understanding. When members of society work together with one mind, they are able to understand themselves better. This enables them to identify their common problems, which require common solutions.

7. Peace helps to promote harmony and progress. When members of a community are able to work together peacefully, they are better able to achieve their common goals, thereby promoting harmony and progress of the community.

8. Peace also helps to promote tolerance and happiness. Working together helps people to develop the spirit of oneness.

9. Peace inculcates the spirit of hard work. When people work together without grudges, they develop a team spirit. Team spirit and hard work lead to harmony and national development.

10. Peace ensures growth, meaningful living and advancement in any society.

Challenges to National Security in Nigeria
Nigeria is a country blessed with abundant human resources. The major challenge to national security in Nigeria is that the Nigerian flag -the national umbrella is not wide enough to protect every one. Those outside either indulge in deviant behaviours or turn to their tribe for solidarity and support. Thus, Nigeria is a country without national consciousness, loyalty or identity. The challenges are itemized as follows:

- There is a large army of unemployed and disillusioned young men and women whose ranks are growing exponentially by the year and who are easily susceptible to expressing their grievances through violence in one form or the other.

- Insurgency, kidnapping, armed robbery and corruption have taken alarming tolls on lives and property in Nigeria, and have badly damaged both national and regional economies of the country.

- There is mutual distrust between government and insurgent groups in Nigeria, thereby making it difficult to have dialogue as an alternative means to achieving lasting peace in the country.

- Mis-governance with its attendant impunity denies government the much needed

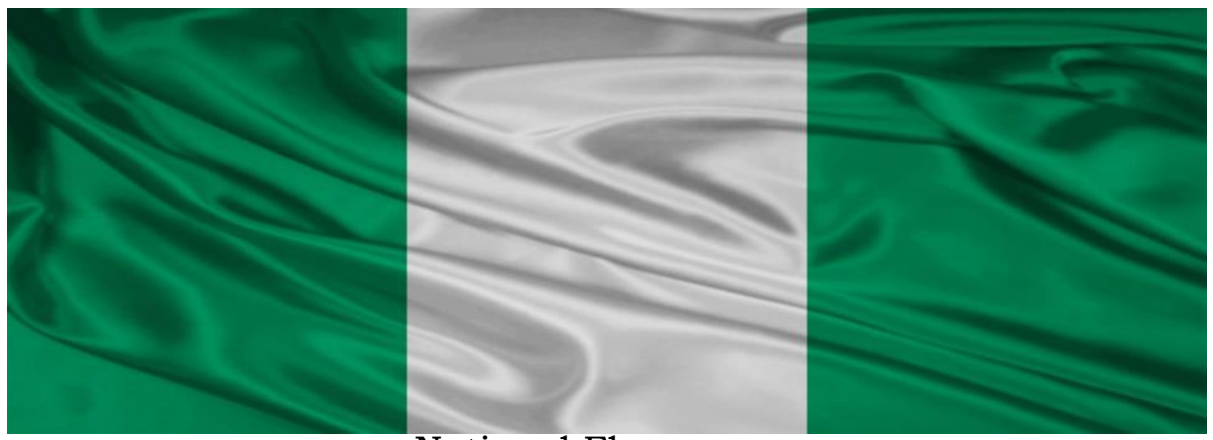

National Flag

http://escipub.com/american-journal-of-educational-research-and-reviews/ 
- sympathy and collaboration of wellmeaning members of society in fighting threats to national unity.

- The Judiciary is considerably weak as a result of insufficient funding and provision of necessary infrastructure and working tools; and is even made weaker by corruption and lack of strong will to hear and determine corruption cases with dispatch as a matter of utmost public policy importance.

- There is no noticeable strong will on the part of government to fight corruption and there is no effort either to find out why citizens suddenly ring themselves about with bombs, or bear arms against the society, to kill and be killed.

- Millions of Nigerian children are in the streets and out of school - about 16 Million in the Northern part of Nigeria alone - and these are potential sources of recruitment for crimes and criminalities

\section{Discussion of some of the challenges}

Street Children: Street children are those children under the age of eighteen who spend most of their lives on the street (UNICEF, 2007). They are either 'abandoned' or 'abandoned themselves' on the street (UNICEF, 2005).

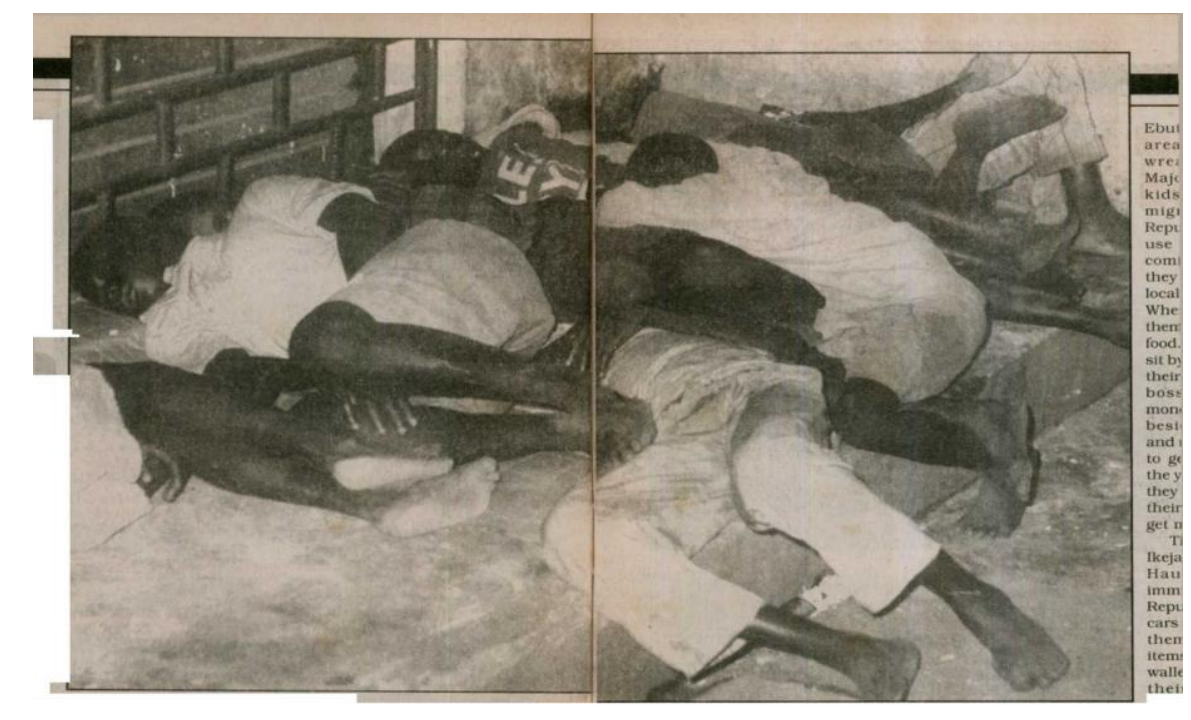

Children of Neglect

TELL, July, 212003

Deferent kinds of street children are found in Nigeria and some of them include:

- Those who live and work on the street (Children of the Street);

- Those who work on the streets full or part-time but who return to their homes each night (Children in the Street); 
- Those usually found in the southern cities although in different form, usually as guides to physically challenged adults (Beggars Street Children);

- Those children and young adults under the guise of filling pot holes on major roads engage in begging and sometimes form part of organized high way robberies as they provide unsuspecting intelligence and sometimes plant sharp objects on the road to puncture and deflate vehicle tyres and trap vehicles for easy plunder by the main armed robbers (Road Children).
- There is another variant of the phenomenon known as street wandering boys and girls roaming the streets doing nothing serious (Street Wanderers).

\section{Religious Crimes/Boko Haram Insurgence:} Jama'atu Ahlis Sunna Lidda'awati Wal-Jihad, better known by its Hausa name Boko Haram, (translated as "Western education is sacrilege" or "a sin") is a jihadist terrorist organization based in the northeast of Nigeria. The movement was responsible for more than 1000 killings in Nigeria. (Eme,2012:47).

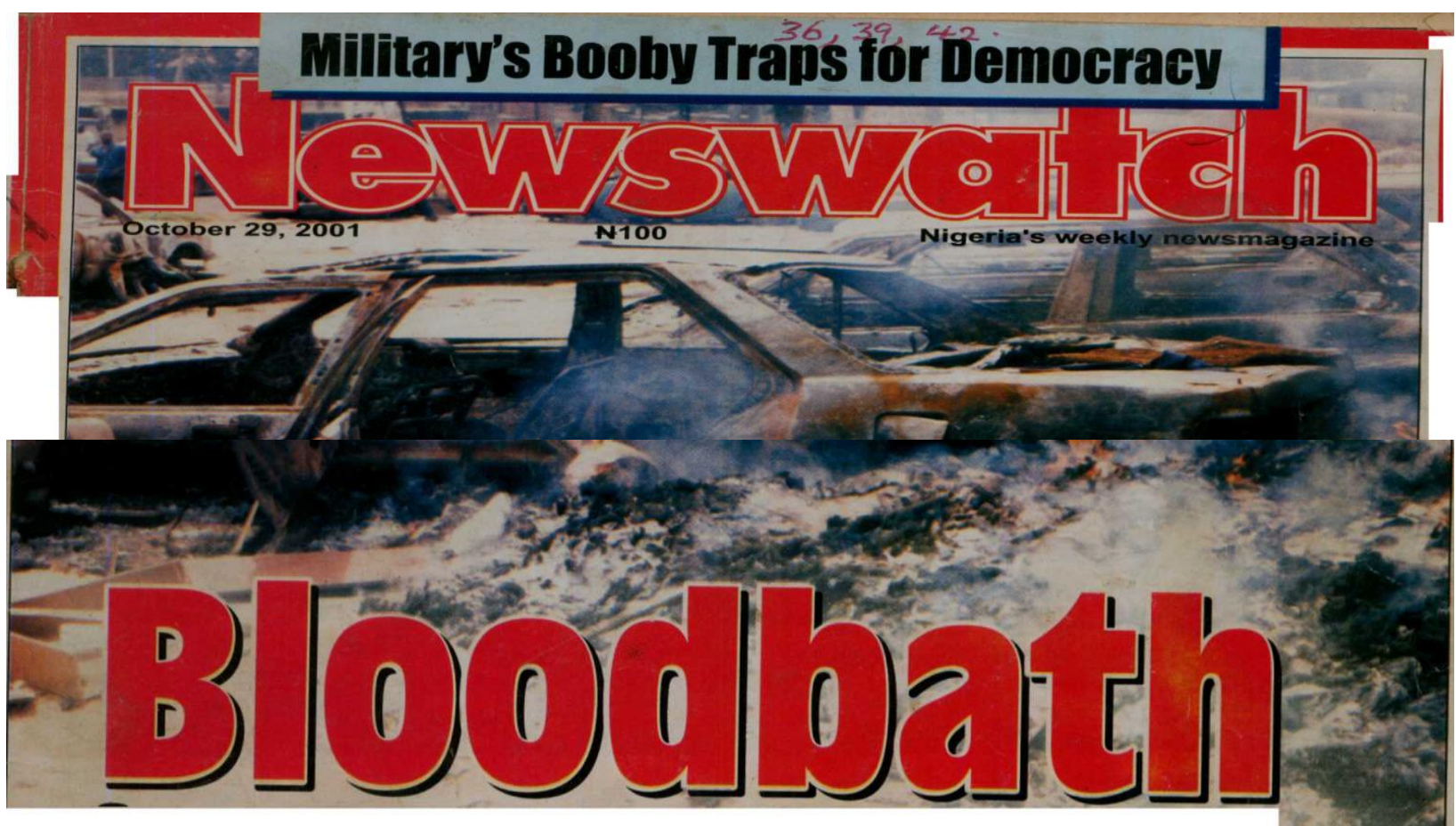

In Kano, Taraba

Bin Laden fanatics wreck havoc Soldiers set for reprisal attack (TELL, JUNE 9, 2003) In Benue Security alert nationwide $\mathrm{CIA} / \mathrm{FBI}$ arrive Nigeria

Since 2009, Boko Haram, for instance has and military targets, media houses, churches been waging almost daily war on Nigeria and mosques. Aside from using stolen and self northern territory especially against the police - made explosives, imported guns and 
ammunitions, Boko Haram members were reported to snatch vehicles at gun points and used the less exotic ones for suicide bombings (Olawale \& Adisa, 2012). Sometimes also, they ride on bicycles with riffles to attack innocent citizens and law enforcement agencies.

Political Alienation: There is a wide gulf between the ruling class and the ruled. Those in power sometimes see it as birth right. Again, most people do not like power shift. Those that want to perpetuate themselves in office feel alienated whenever power, especially the presidency, shifts to the other side.

High Rate of Poverty: That poverty exists in Nigeria and reflected in the quality of life of the average Nigerian citizen. In defining poverty,

\section{Faces of Poverty in Nigeria}

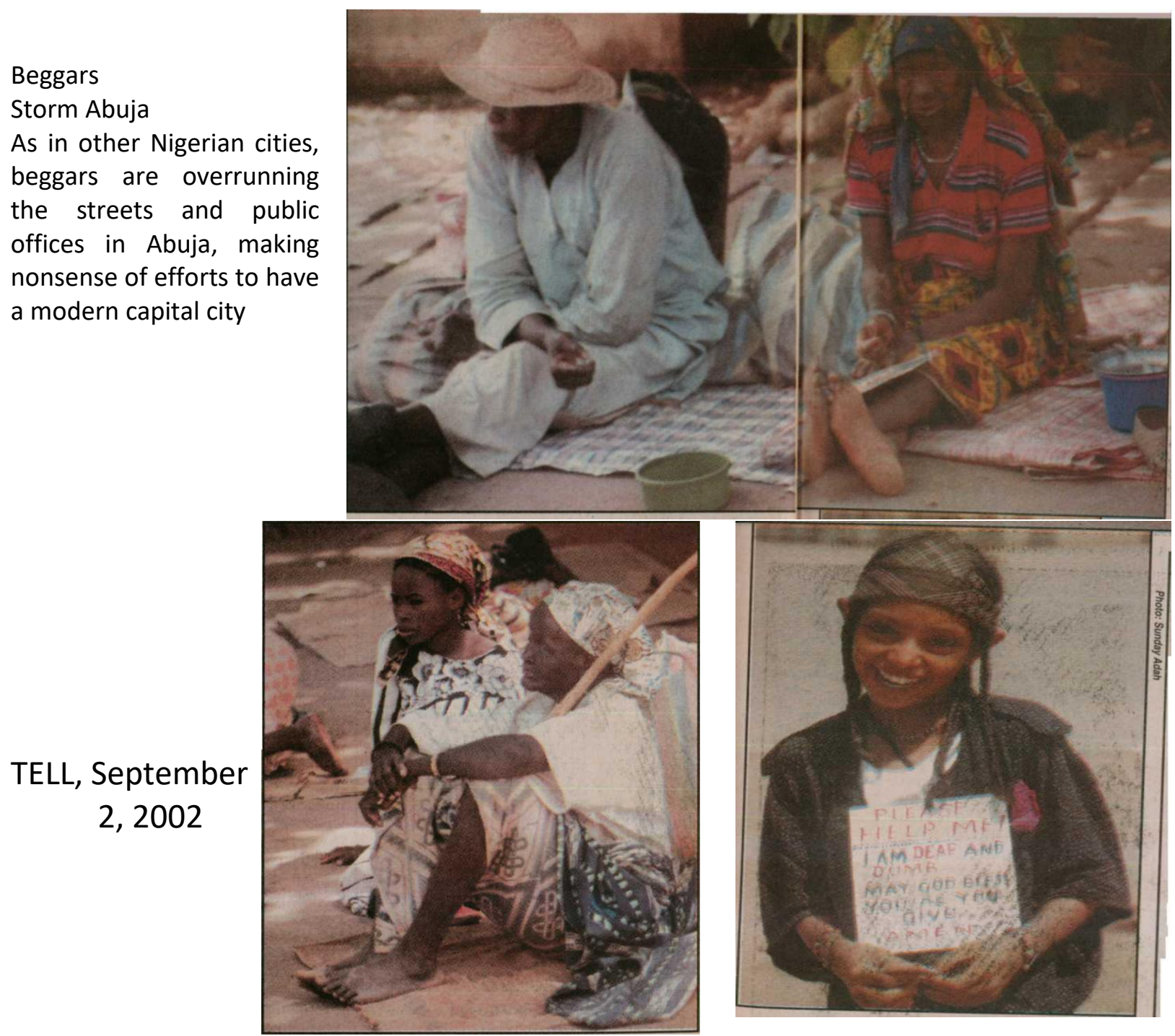

Poverty is a state of deprivation, in terms of are inadequate to support a minimum standard both economic and social indicators, such as of decent living.

income, education, health care, access to food, Edoh (2003) citing the vision 2010 Committee social status, self-esteem and self-actualisation. Report, revealed that:

It exists when income or disposable resources 
- $50 \%$ Nigerians live below the poverty authorities. It is also directly responsible for line. crime in the cities as well as the rural areas

- Only about $40 \%$ has access to safe (HRW, 2007). According to Quinney (1980) drinking water.

crime is a direct product of poverty and as

- About $85 \%$ of the urban population lives revealed by HDR (1996), poverty contributes to in single rooms with more than seven occupants on the average.

- Only about $62 \%$ of Nigerians have access to primary health care.

Most Nigerians take less than one-third of the minimum required protein and vitamins.

Poverty creates grievances and resentment who are poor because there are no jobs for against the power elite and the ruling them.

\section{Ethnic Militia in Nigeria}

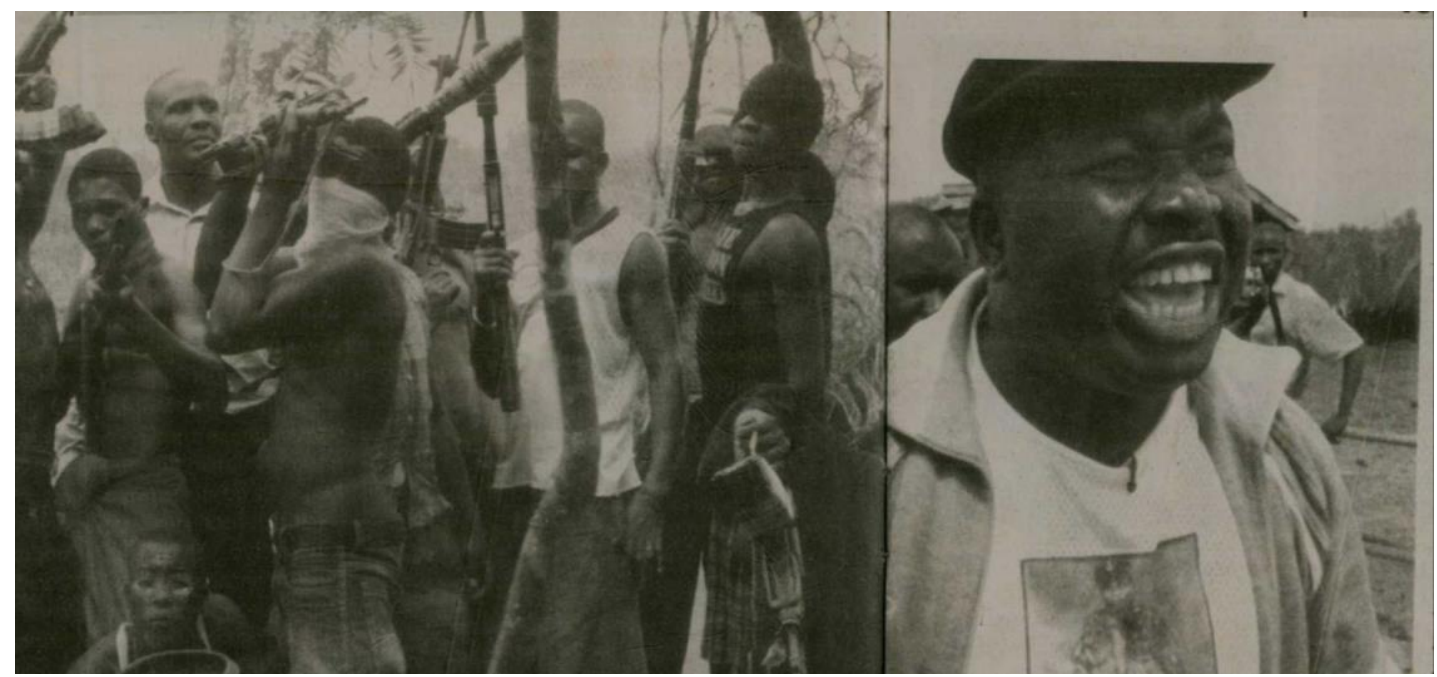

THE NEWS AUGUST, 22, 2005

\section{BAKASSI BOYS' HORROR CELL}

\section{HOW 32 DETAINEES D TO DEATH}

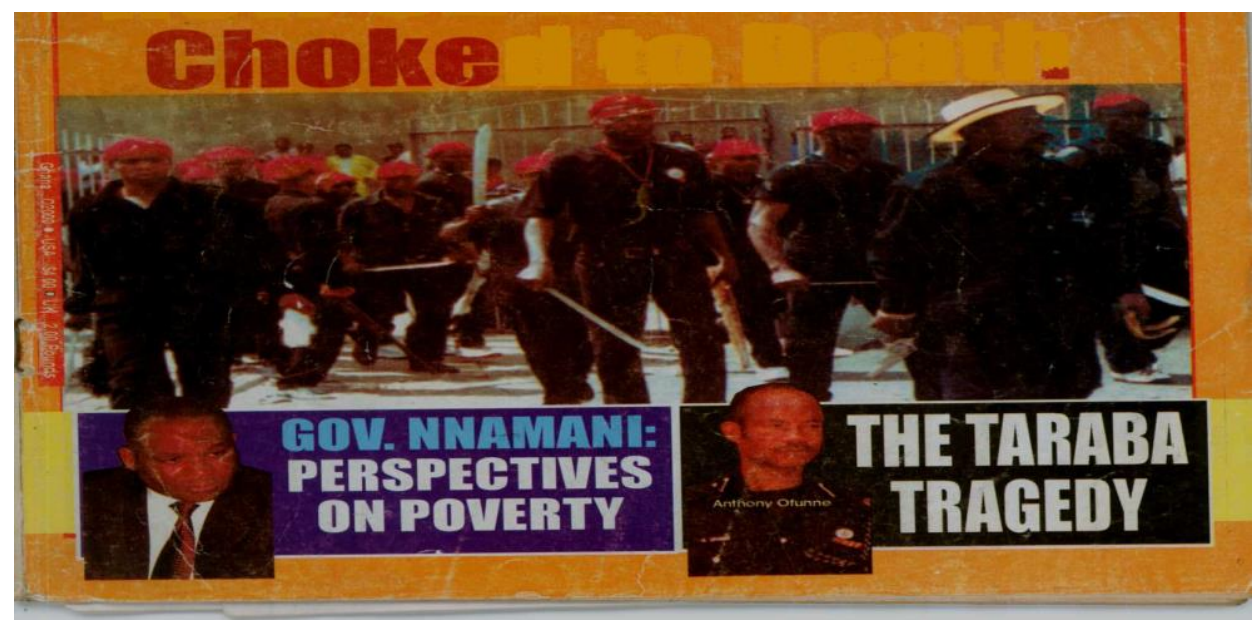

http://escipub.com/american-journal-of-educational-research-and-reviews/ 
Graduate unemployment has become a major social problem. Nwankwo, Omebe and Nwogbo (2012) lamented this when they stated that many of the Nigerian youth found it increasingly difficult to gain employment in the formal sector or end up working in poor conditions in the informal economy.

Strategies for Enhancing Peace Education for National Security in Nigeria

Any meaningful effort to enhance national security in Nigeria through peace education must start from the individual to the government level. The strategies as suggested by Nwankwo, Omebe, and Nwogbo, (2012) are as follows:

Individual Level: The individual Nigerian is the first and most important target for peace education. At this level, peace education can focus on the individuals' sense of worth, identity, relationship with others and general culture of tolerance, and respect for others and their views.

Family Level: This is the primary cell of the society and forms of the informal school for educating the citizens on the virtue of peace, tolerance and mutual respect. If parents live in peace, teach their children tolerance, respect, positive values, then, foundation of peace education will be laid in the country.

Community Level: There is no community without disagreement or conflicts. However, there are community structures that manage such occurrences and facilitate the existence of culture and climate of peace. The structures interact with other means of social order to promote peace in community.

Government Level: Government at levels can be creators of peace, promoters of peace education, sponsor of peace efforts. Government can address issues of poverty, deprivation and other unfulfilled promises as a way of enhancing peace education for national security.

\section{Conclusion}

Peace education is not just about adding topics or themes to the curriculum. It is about mind transformation through the acquisition of appropriate skills, values and attitude which will empower the learner to seek and maintain peace. The implication is that peace education goes beyond subject matter issues to include all aspects of learning that touch on the behaviour of the learner. Non-violence and a holistic peace education framework need to be integrated into curriculum areas in terms of content (knowledge and texts) and pedagogies (participatory and cooperative) and as well, in our inter-personal relations.

\section{Suggestions}

- Government should make conscious efforts at achieving comprehensive and sustainable peace and these efforts should be geared towards attaining economic peace, political peace, educational peace, legal peace and military peace.

Governments at all levels should, as a matter of urgency, introduce scholarship schemes for the singular purposes of taking the loitering millions of children off the streets and into schools - 
possibly boarding schools - and thereby keep them away from the reach and influence of crimes of different shades and colours.

- Government should put in place anti-reprisal mechanism whereby victims of violence and insurgency are quickly pacified and economically restored and rehabilitated.

- Government should create a transparent and trust-worthy mechanism for dialoguing with insurgents as well as for addressing their grievances.

\section{REFERENCES}

Edoh, T. (2003). Poverty and the Survival of Democracy in Nigeria in Nigerian Journal of Political andAdministrative Studies. Vol. 1, No. 4.

Eme, O.I. (2012), "Activities of Boko Haram and Insecurity Question in Nigeria, AJBMR Vol. 1 (9), April, Pp77-99.

Human Rights Watch (2007) Criminal Politics and 'Godfatherism' in Nigeria, New York.

Human Development Report, Nigeria (1996). United Nations Development Programme, Lagos, Nigeria.

Mohammed, A. (2006) "Meeting Current Challenges of National Security" Lecture Delivered to Participants of National War College, Abuja, Nigeria, February 14 Mesa.

Nwankwo, I.N., Omebe, C.A., \& Nwogbo, V.N. (2012). Towards Revitalizing Nigerian University System through Strategic Thinking and Planning. Paper Presented at the Thematic Paper Session of the 42nd Annual Meeting of the International Society for Educational Planning (ISEP), Kansas City, M.O. USA, October 10tTH - 13TH.

Olawale, R. and Adisa, T. (2012). „Boko Haram: Sahel joint military command invites Nigeria, as suspects demand full protection, pledge cooperation with security agents". Sunday Tribune, 26th February, 2012, p. 9.

Obasanjo, O. (1999) "Grand Strategy for National Security" The Presidency, Abuja.

Quinney, R. 1980. Class, State and Crime. London: Longman.
- At family and society levels, elders should show good examples and inculcate in the children, the culture of tolerance and coexistence in the plural society, as well as teaching them patriotism and civic responsibilities to the nation over and above allegiance to tribe or ethnicity.

- The media - i.e. print, electronic and social are to be enlisted in the collective effort at reshaping the mind and character of the youth towards tolerance and peaceful co-existence.

\footnotetext{
UNICEF (2005) The State of the World's Children, Oxford University Press.
}

UNICEF (2007) The State of the World's Children.

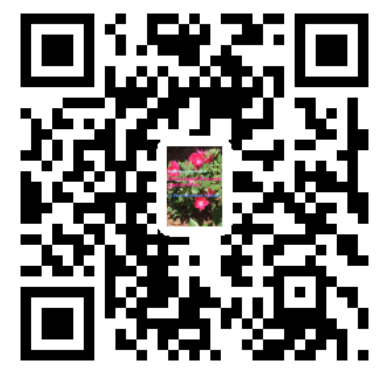

